are devoted to electric railways. The method of giving two tables for the same constant in two separate parts of the book is open to much criticism, and there are one or two obvious mistakes. In the description of the Weston cadmium cell, for example, the elements are stated to be cadmium and mercury instead of cadmium amalgam and mercury, while in the table of specific inductive capacities on p. 227 the specific inductive capacity of gutta-percha is given as 2.5 , whereas on p. 36 we have the proper value of from $33-49$. The whole of the table on p. 227 might well be omitted. Apart from a few minor defects, which it is very difficult to avoid in a compilation of this kind, the tables appear to be trustworthy, and are readily referred to by the aid of an excellent and complete index.

E. W. M.

\section{FOOD AND NUTRITION.}

Human Foods and their Nutritive Value. By $\mathrm{H}$. Snyder. Pp. xvi+362. (New York: The Macmillan Co.; London: Macmillan and Co., Ltd., I908.) Price $5^{\text {s. net. }}$

UR author remarks that the study of foods is " the oldest, most important, most neglected, and least understood of any that have a direct bearing upon the welfare of man."

No doubt there has been, and still is, neglect of systematic and coordinated scientific investigation into the many problems which arise in connection with the task of nourishing the human body. Yet a vast amount of work has been done on the subject. The list of books referred to in the present volume reaches the respectable total of one hundred. True, many of them-as, for example, the "Bulletins" of the United States Department of Agriculture-are only short studies of isolated points, but, on the other hand, the list is chiefly confined to American works, and is not intended to be a complete bibliography. Perhaps the indications point not so much to general neglect as to the present stage being one of accumulating evidence. By and by, it may be, some dietetic Kepler will discover laws of nutrition which will coordinate the facts better than can yet be done. Meanwhile, distinct progress is being made.

The opening chapter of the volume is devoted to expounding the general composition of foods. It describes how they are made up of water, inorganic salts, and organic compounds, and how the latter may consist of proteids and fats, starches, sugars, pectose, cellulose, and so on. After explaining the changes which foods undergo during cooking, the author passes to a consideration of the various classes of foods--e.g. vegetables, fruits and flavourings, milk and other dairy products, meat-foods, cereals, condiments, and beverages. In each case a short description of the article is given, indicating its composition as regards nutrient substances and, generally, its value as a food. Tables are appended which show, for ordinary American foodstuffs, the proportion of nonedible refuse, water, protein, fat, carbohydrates, and ash, together with the heat-equivalents of the foods.
Naturally in so small a book the information is often meagre, but it appears to be generally trustworthy. The treatment, though elementary, should serve to make the work a good introduction to the study of dietetics.

Probably the sections dealing with the digestibility of foods and with dietary studies will be found the most interesting. The author distinguishes between the completeness and the ease of digestion, and summarises the factors which influence the two as (I) combination of foods, (2) amount, (3) method of preparation, (4) mechanical condition of the food, (5) its palatability, (6) its physiological properties, such as astringency and laxativeness, (7) the individuality of the consumer, and (8) psychological influences-e.g. preconceived ideas as to the wholesomeness or otherwise of the food. On such questions as vegetarianism, the use of "whole-meal" bread, and heavy meat diets, Mr. Snyder takes a moderate and reasoned attitude. As regards the last, he maintains that at present the available results are too meagre to justify the formulation of other than tentative standards. "In the matter of diet," he says, quoting Hutchison's "Food and Dietetics," "every man must, in the last resort, be a law unto himself ... giving due heed to the warnings which nature is sure to address to him should he at any time transgress."

C. Simmonds.

\section{THE BODY AT WORK.}

The Body at Work. A Treatise on the Principles of Physiology. By Dr. Alex. Hill. Pp. xi +448 . (London : Edward Arnold, 1908.) Price I6s. net.

$\mathrm{D}^{\mathrm{R}}$. HILL has given us a book at once instructive and attractive. He writes for the amateur in science, but men deeply versed in physiology will find much to interest and to learn in his work. There is not a sentence in the book that could be spared, yet, although the reading commands close attention, it never fails to attract and to please. After a preliminary review of the subject of physiology, the second chapter, on the basis of life, reminds one of the great man whose name appears in the first line of the chapter, for "The Body at Work" is quite in the style of Huxley at his best.

The subject is approached from the unit of structure-the cell-through its groupings and specialising of structure and function tc form the higher tissues and organs. The importance of the leucocytes, their manner of travelling, of multiplying, and of grouping, is graphically told, and the sections devoted to the blood and circulation in chapters iv. and ix. are simply but most explicilly handled. Amateurs in science can peruse with understanding the abstruse subjects of the functions of the thyroid gland, the suprarenal capsules, and the pituitary body. Digestion and dietetics, respiration in all its bearings, absorption and excretion are given in language that reads almost like a fairy-tale, yet with a scientific accuracy and bearing wholly trustworthy.

Throughout the book the meaning of vital processes is brought out in a fashion which leaves its impress. NO. 2065 , VOL. 80] 